\title{
Application of normal essential oil and loaded-solid lipid nanoparticles as antioxidant
}

\author{
M. G. Taha ${ }^{1}$, M. M. EL-Dannasoury ${ }^{1,}{ }^{*}$, S. A. Mahmoud ${ }^{2}$ and M. E. Moghazy ${ }^{2}$ \\ ${ }^{1}$ Biochemistry Department, Faculty of Agriculture, Al-Azhar University, Cairo, Egypt \\ ${ }^{2}$ Meat and Fish Technology Research Department, Food Technology Research Institute, Agriculture Research \\ Center, Giza, Egypt \\ * Corresponding author E-mail: mdanasory@azhar.edu.eg (M. EL-Dannasoury).
}

\begin{abstract}
The industry adds antioxidants in the formulation of meat products to prevent or delay meat oxidation reactions. Therefore, this investigation was carried out to study the effect of normal essential oil and loaded-solid lipid nanoparticles as antioxidants and the effect of the abovementioned volatile oils on chemical properties (TBA) and shelf life of frozen beef burger. The antioxidant activity of volatile oils (cinnamon and ginger) normal and nano particle size at different concentrations were assessed. Also, the effect of the above mentioned volatile oils addition with different concentrations on chemical properties and shelf life of frozen beef burger was investigated. Results indicated that, the diphenylpicrylhydrazyl free radical scavenging activity increased by increasing the volatile oil concentrations for all studied treatments. Moreover, the antioxidant activity of volatile oils (cinnamon and ginger) nanoparticles was higher than that of the same concentrations of normal volatile oil. The chemical properties values thiobarbituric acid value (TBA) of beef burger decreased by increasing volatile oils concentrations and essential oils nanoparticles reduced chemical properties (TBA) values more than normal essential oils, beside extending the shelf life of beef burger treatments up to 6 months in comparison with control sample which have a four-month shelf life. In conclusion, the transformation of essential oils into nanoparticle size can affect their antioxidant activity and promote the chemical properties and shelf life of beef burger.
\end{abstract}

Keywords: Volatile oils; Antioxidant; Cinnamon; Ginger.

\section{INTRODUCTION}

Cunha et al. (2018) explained that to prevent or delay meat oxidation reactions, the industry adds antioxidants in the formulation of meat products. However, the majority of these ingredients are synthetic mainly butylated hydroxyanisole (BHA), butylated hydroxytoluene (BHT) and propyl gallate (PG). Nevertheless, some studies have shown the adverse effects of the synthetic antioxidants on the consumer's health, thereby increasing the demand for natural antioxidants. On the other hand, compounds with antioxidant activity can be naturally found in plants, oils, fruits, nuts, and several studies have shown the efficacy of the substitution of natural antioxidants for the synthetic ones. Nonetheless, the effectiveness of natural antioxidants in meat products depends mainly on the composition of vegetable extracts and their antioxidant activity, application form, food processing, and meat matrix, especially the composition of the lipid and protein fraction.

Moreover, Si et al. (2018) reported that lipid oxidation is a major cause of food product deterioration. Consequently, it is a necessary to use food additives to inhibit food oxidation. Ginger extract (GE) possesses antioxidant properties. However, components isolated from ginger have been rarely reported to inhibit fat oxidation. Herein, antioxidant properties of GE and four pure components derived from it (6-gingerol, 8-gingerol, 10- gingerol, and 6shogaol) were examined and their properties were compared to those of butylated hydroxytoluene. GE and the constituent components exhibited antioxidant properties that might be attributed to their hydroxyl groups and suitable solubilizing side chains.

Ghani et al. (2018) reported that the new bioactive film from soluble soybean polysaccharide (SSPS) incorporated with different concentrations of cinnamon essential oil nanoemulsions $(\mathrm{CNO})$ and their functional properties were evaluated. Then CNO-SSPS film was applied to meat refrigerated for 8 days. The use of CNO in film production has reduced thickness, water vapor permeability, water solubility, lightness $\left(\mathrm{L}^{*}\right)$, redness $\left(\mathrm{a}^{*}\right)$ and whiteness (WI) and increased antioxidant activity of SSPS-films.

\section{MATERIALS AND METHODS}

\section{Meat and fat tissues}

Imported frozen beef meat and fat tissues (sheep tail) were purchased from the private sector shop in the local market at Giza, Egypt.

The chosen spices 
Cinnamon bark (Cinnamon cassian) and Ginger roots (Zingiber officinale Roscoe) were obtained from a spices shop at Giza, Egypt. The dried spices were ground into a fine powder and kept frozen at $-18^{\circ} \mathrm{C}$ in polyethylene bags until extraction of volatile oil.

\section{Ingredients used in burger formula}

Texturized Soy was obtained from Food Technology Research Institute, Agricultural Research Center, Giza, Egypt. It was rehydrated by water (at a ratio of 1:2 w/v) and minced through $3 \mathrm{~mm}$ plate twice. Bread crust, egg, salt, fresh onion and spices were purchased from local market at Giza, Egypt. The spices were powdered in a laboratory mill, and then a mixture of the powdered spices was prepared as follows: $8.91 \%$ laurel leaf powder; $6.01 \%$ cardamom; $6.86 \%$ nutmeg; $14.08 \%$ cinnamon, $11.22 \%$ clove, $9.14 \%$ thyme, $29.39 \%$ cubeb and $14.39 \%$ white pepper.

\section{Extraction of spices volatile oils}

Extraction of volatile oil from Cinnamon bark (cinnamon cassian) and Ginger roots (Zingiber officinale Roscoe) were carried out by Hydro distillation method according to A.O.A.C. (1995).

Cinnamon and ginger essential oil loadedsolid lipid nanoparticles (EO-SLNs) preparation

Solid lipid nanoparticles (SLNs) were prepared using ultrasonic solvent emulsification technique according to Asnawi et al. (2008).

\section{Determination of essential oil loading efficiency}

The encapsulation efficiency (EE) of cinnamon and ginger volatile oils were determined as described by Tiyaboonchai et al. (2007) and Nayak et al. (2010).

\section{Transmission electron microscopy (TEM)}

Structural characterization and the morphology of oil loaded SLNs were observed with JEOL JEM-2100 transmission electron microscopy (TEM).

\section{Preparation of beef burger}

Beef burger was prepared as described by Mikkelson (1993).

\section{Analytical Methods}

Thiobarbituric acid value (TBA)

The TBA as an indicator of secondary lipid oxidation was determined as the method described by Tarledgis et al. (1960).

\section{Statistical analysis}

Obtained data were subjected to analysis of variance (ANOVA). Means were compared by using Duncans test at the $5 \%$ level of probability as reported by Snedecor and Cochran (1995).

\section{RESULTS AND DISCUSSION}

\section{Separation and identification of spice volatile oils}

\section{Volatile oil content of investigated spices}

Volatile oils were extracted from the two investigated spices by steam distillation and their percentages were determined. From the obtained data in Table (1) it could be observed that, the volatile oils percentages in the investigated spices were 1.30 and $1.20 \%$ for cinnamon bark and ginger rhizome respectively. These results are in agreement with those obtained by (Sharma et al., 2016) who reported that the yield of ginger root essential oil ranged from 1 to $2 \%$ in freshly ground ginger root.

Table 1. Essential oils content in cinnamon bark and ginger rhizome.

\begin{tabular}{cc}
\hline Spices & Volatile oil \% $(\mathrm{v} / \mathrm{w})$ \\
\hline Cinnamon bark & 1.30 \\
Ginger rhizome & 1.20 \\
\hline
\end{tabular}

On the other hand, Wang et al. (2009) reported that the yield of cinnamon bark essential oil ranged from 0.65 to $2.50 \%$ in freshly ground cinnamon bark.
Cinnamon and Ginger essential oils loaded with solid lipid nanoparticles and its characterization

Oil encapsulation efficiency (EE) is a critical factor for nanoparticles. A good nano carrier should have high oil encapsulation efficiency. 
The results show the encapsulation efficiency in the stearic acid as coating nanoparticles. It was positively correlated to the amount of Cinnamon and Ginger essential oils, that it is increased with the increasing oil concentration to stearic acid. Data showed that the encapsulation efficiency of Cinnamon and Ginger oils nanoparticles significantly increased at the concentration 25\%. The morphology and characterization of Cinnamon and Ginger oils loaded solid lipid nanoparticles at different concentrations to stearic acid as coating material were visualized using transmission electron microscopy (TEM).

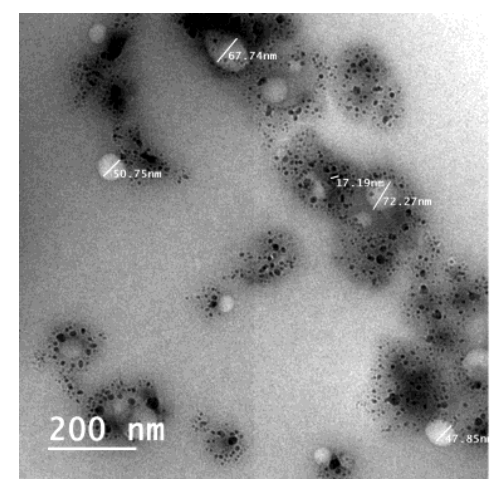

Figures (1 and 2) show the particles appearing round, spherical in shape, a good dispersion and narrow size distribution, when Cinnamon and Ginger oils used at 25\% conc. the particle size seems to be larger (ranging 50-70 nm) (Figure, 1), These results are in agreement with Yang et. al., (2009), they recorded that the oilloading efficiency could reach $80 \%$ at the optimal ratio of garlic essential oil to $10 \%$ of polyethylene glycol (PEG) and proportion for other nano systems. Gomah and Nenaah (2014) detected that the sizes polydispersion index (PDI) and loading efficiency for eight

Figure 1 (a and b). TEM micrograph of cinnamon volatile loaded-solid lipid nanoparticles (EO-SLNs) $25 \%$ conc.
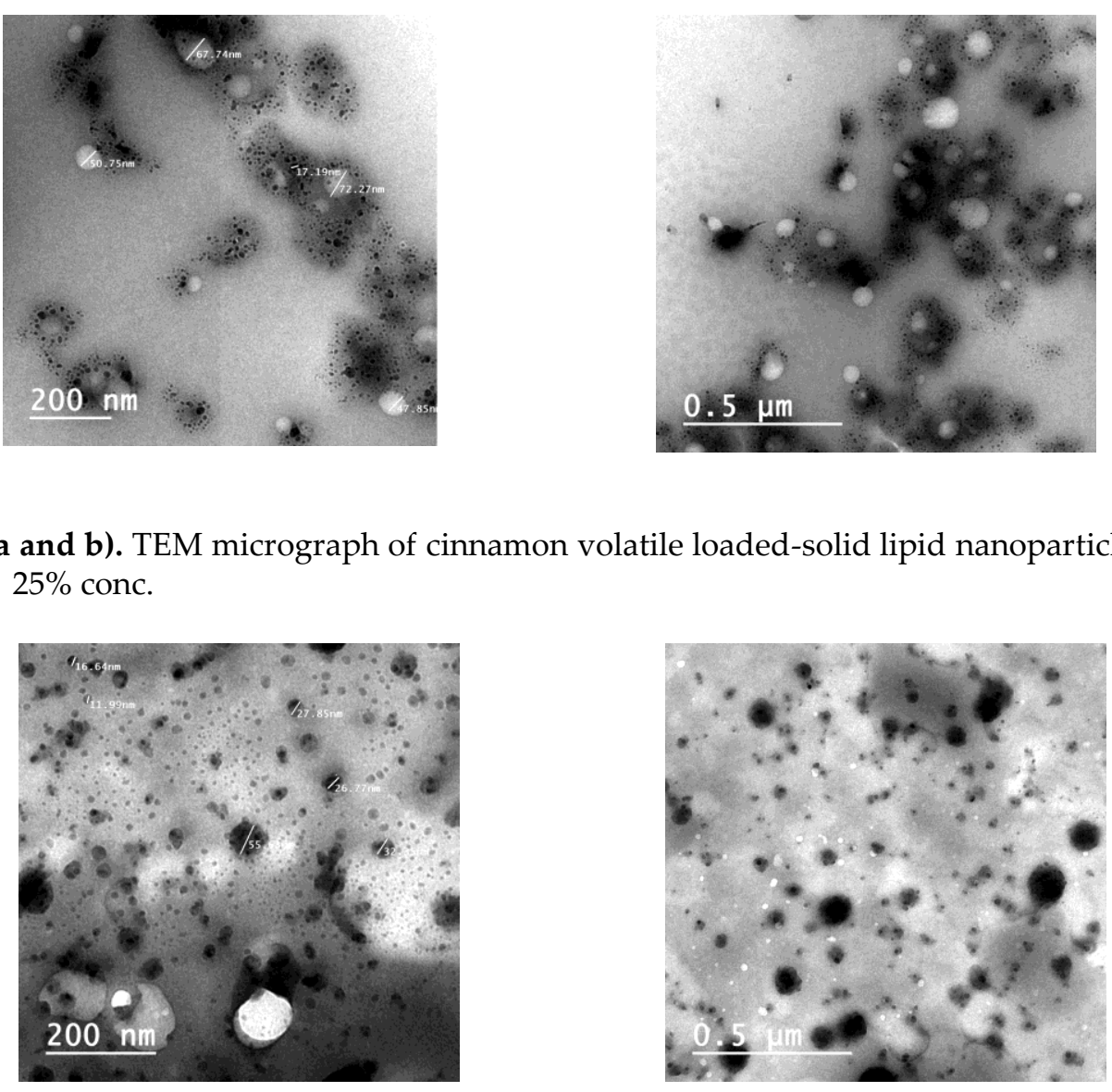

Figure 2 (a and b). TEM micrograph of ginger volatile oil free and loaded-solid lipid nanoparticles (EOSLNs) $25 \%$ conc.

essential oil-nanoparticles, the $10 \%$ ratio EOPEG showed the best relationship between a low PDI (which measure the size of distribution of nanoparticles) and a high loading efficiency.

\section{Antioxidant activity of volatile oils}

Diphenylpicrylhydrazyl (DPPH) radical scavenging activity

Data given in Table (2) showed the radical scavenging activity of two different volatile oils (cinnamon and ginger) free and loaded-solid 
lipid nanoparticles (EO-SLNs) used in this study compared with BHT as a synthetic antioxidant. From the obtained results, it could be evidenced that, the free radical scavenging activity of all volatile oils is lower than that of BHT. The highest DPPH free radical scavenging activity (\% inhibition $95.12 \%$ ) was recorded for cinnamon volatile oil nano followed by ginger volatile oil nano $(90.25 \%)$. On the other hand, the lowest scavenging activity (72.12\%) was observed for ginger volatile oil free. These results are in line with those obtained by Wang et al. (2008), who found that, cinnamon volatile oil had the highest DPPH radical scavenging activity when compared with clove, ginger, cardamom and coriander volatile oils. On the other hand, antioxidants are believed to intercept the free radical chain of oxidations, and to contribute hydrogen from the phenolic hydroxyl groups themselves, thereby forming stable free radicals which do not initiate or propagate further oxidation of lipids (Si et al., 2018).

Table 2. DPPH radical scavenging effect of three different volatile oils and their nano particle compared with BHT.

\begin{tabular}{cc}
\hline Volatile oils & DPPH free radical scavenging $(\%)$ \\
\hline Cinnamon & 83.25 \\
Ginger & 72.10 \\
Cinnamon nanopartical & 95.12 \\
Ginger nanopartical & 90.25 \\
BHT & 97.28 \\
\hline
\end{tabular}

These results explain that the volatile oils have effective activity as a hydrogen donor and as a primary antioxidant by reacting with the lipid radical. This may be responsible for the main cause of suppression of autoxidation, in DPPH assay.

\section{Chemical properties of beef burger}

Thiobarbituric acid (T.B.A) values

TBA test is a sensitive test for the decomposition products of highly unsaturated fatty acids which do not appear in peroxide value determination (Mohamed, 2005).

Table 3. Thiobarbituric acid (mg malonaldehyde/kg) of different beef burger treatments as affected by cinnamon essential oil (normal and nanoparticle) and their percentages during frozen storage at $-18^{\circ} \mathrm{C}$ up to 6 months.

\begin{tabular}{|c|c|c|c|c|c|c|c|c|}
\hline \multirow{3}{*}{$\begin{array}{l}\text { Storage } \\
\text { period } \\
\text { (months) }\end{array}$} & \multirow{3}{*}{ Control } & \multicolumn{6}{|c|}{ Treatments } & \multirow[t]{3}{*}{ LSD } \\
\hline & & \multicolumn{3}{|c|}{ Cinnamon essential oil (\%) } & \multicolumn{3}{|c|}{ Cinnamon nano-particale (\%) } & \\
\hline & & 0.05 & 0.1 & 0.15 & 0.05 & 0.1 & 0.15 & \\
\hline Zero time & $0.274^{\mathrm{Ad}}$ & $0.280^{\mathrm{Ad}}$ & $0.271^{\mathrm{Ad}}$ & $0.278^{\mathrm{Ad}}$ & $0.279 \mathrm{Ad}$ & $0.275^{\mathrm{Ae}}$ & $0.277^{\mathrm{Ad}}$ & $0.182^{\mathrm{ns}}$ \\
\hline 1 & $0.479^{A d}$ & $0.381^{\mathrm{Ac}}$ & $0.377^{\mathrm{Ac}}$ & $0.365^{\text {Acd }}$ & $0.367^{\mathrm{Ad}}$ & $0.335^{\mathrm{Ab}}$ & $0.314^{\mathrm{Ac}}$ & $0.171^{\mathrm{ns}}$ \\
\hline 2 & $0.652^{\mathrm{Ac}}$ & $0.599 \mathrm{ABb}$ & $0.597 \mathrm{ABC}$ & $0.572^{\mathrm{Bc}}$ & $0.482^{\mathrm{Ac}}$ & $0.445^{\mathrm{ABd}}$ & $0.402^{\mathrm{Ac}}$ & $0.165^{*}$ \\
\hline 3 & $0.866^{\mathrm{Ab}}$ & $0.687^{\mathrm{AB} a b}$ & $0.659^{\mathrm{Bbc}}$ & $0.611^{\mathrm{Cbc}}$ & $0.600^{\mathrm{Bbc}}$ & $0.560^{\mathrm{ABd}}$ & $0.511^{\mathrm{ABb}}$ & $0.153^{*}$ \\
\hline 4 & $1.672^{\mathrm{Aa}}$ & $0.791^{\text {Bab }}$ & $0.780^{\mathrm{BCb}}$ & $0.722^{\mathrm{Db}}$ & $0.684^{\mathrm{BCab}}$ & $0.629 \mathrm{BCc}$ & $0.597^{\mathrm{ABb}}$ & $0.972^{*}$ \\
\hline 5 & ----- & $0.899^{\text {ва }}$ & $0.843^{\mathrm{Ca}}$ & $0.811^{\mathrm{Dab}}$ & $0.780^{\mathrm{Ca}}$ & $0.712^{\mathrm{BCcb}}$ & $0.681^{\mathrm{Bb}}$ & $0.091^{*}$ \\
\hline 6 & ----- & ---- & $0.951^{\mathrm{Ca}}$ & $0.913^{\mathrm{Ba}}$ & $0.843^{\mathrm{Aa}}$ & $0.794 \mathrm{Ca}$ & $0.740^{\mathrm{Ba}}$ & $0.009^{*}$ \\
\hline LSD & $0.168^{*}$ & $1.35^{*}$ & $0.149^{*}$ & $0.154^{*}$ & $0.145^{*}$ & $0.145^{*}$ & $0.132^{*}$ & \\
\hline
\end{tabular}

Where: Mean values in the same row (as a capital letter) or column (as a small letter) with the same letter are not significantly differences at 0.05 level;LSD: Least significant differences; Ns: Non-significant differences; ${ }^{*}$ significant differences. 
Data given in Table ( 3 and 4 ) showed the changes of thiobarbituric acid values (mg malonaldehyde/kg sample) of different beef burger treatments as affected by two type of volatile oils (cinnamon and ginger) normal and loaded-solid lipid nanoparticles (EO-SLNs) and their percentages $(0.05,0.1$ and $0.15 \%)$ during frozen storage period at $-18{ }^{\circ} \mathrm{C}$ up to 6 months. From these results, it could be noticed that, there were no significant differences $(\mathrm{P}>0.05)$ in thiobarbituric acid (TBA) between different beef burger treatments immediately after processing and after one month of frozen storage. Also, non-significant differences $(P>0.05)$ were recorded between control sample and beef burger treatments prepared with ginger volatile oil free at $0.05 \%$ and after two months of frozen storage. On the contrary significant differences $(\mathrm{P}<0.05)$ were observed between control and beef burger prepared with ginger volatile oil free at $0.15 \%$. Meanwhile significant differences $(\mathrm{P}>0.05)$ were recorded between control sample and beef burger treatments prepared with cinnamon volatile oil normal and after zero time of frozen storage at any concentration.At zero time of frozen storage, thiobarbituric acid values of different beef burger treatments ranged between 0.271 and $0.280 \mathrm{mg}$ malonaldehyde/kg sample. These results are in line with those obtained by Hassan (2010) who found that TBA values of beef burger samples ranged between 0.498 to $0.785 \mathrm{mg}$ malonaldhyde/Kg samples.

These values increased significantly by increasing storage time to range between 0.597 and $1.657 \mathrm{mg}$ malonaldehyde/ $\mathrm{kg}$ sample at 4 th month of frozen storage. The highest thiobarbituric acid value $1.672 \mathrm{mg}$ malonaldehyde/kg sample was recorded for control sample followed by beef burger prepared with $0.05 \%$ ginger volatile oil with significant differences between them. Meanwhile the lowest values $(0.597 \mathrm{mg}$ malonaldehyde/kg sample) was recorded for beef burgers treatments prepared with $0.15 \%$ cinnamon volatile oil nano followed by beef burger prepared with $0.15 \%$ ginger volatile oil nano with significant differences. During frozen storage at $-18{ }^{\circ} \mathrm{C}$ up to 6 months, thiobarbituric acid values of all beef burger treatments either control sample or

Table 4. Thiobarbituric acid (mg malonaldhyde/kg) of different beef burger treatments as affected by ginger essential oil (normal and nanoparticle) and their percentages during frozen storage at $-18^{\circ} \mathrm{C}$ up to 6 months.

Treatments

\begin{tabular}{|c|c|c|c|c|c|c|c|c|}
\hline \multirow{2}{*}{$\begin{array}{r}\text { Storag } \\
\text { e period } \\
\text { (months) }\end{array}$} & \multirow[t]{2}{*}{ Control } & \multicolumn{3}{|c|}{ Ginger essential oil (\%) } & \multicolumn{3}{|c|}{ Ginger nano-particle (\%) } & \multirow[t]{2}{*}{ LSD } \\
\hline & & 0.05 & 0.1 & 0.15 & 0.05 & 0.1 & 0.15 & \\
\hline Zero time & $0.274^{\mathrm{Ad}}$ & $0.274^{\mathrm{Ad}}$ & $0.276^{\mathrm{Ae}}$ & $0.273^{\mathrm{Af}}$ & $0.277^{\mathrm{Ae}}$ & $0.276^{\mathrm{Ae}}$ & $0.277^{\mathrm{Ad}}$ & $0.182^{\mathrm{ns}}$ \\
\hline 1 & $0.479 \mathrm{Ad}$ & $0.422^{\mathrm{Bd}}$ & $0.411^{\mathrm{Bd}}$ & $0.392^{\mathrm{Af}}$ & $0.377^{\mathrm{Ae}}$ & $0.363^{\mathrm{Ad}}$ & $0.372^{\text {Acd }}$ & $0.171^{\mathrm{ns}}$ \\
\hline 2 & $0.652^{\mathrm{Ac}}$ & $0.625^{\mathrm{BCc}}$ & $0.605^{\mathrm{Cc}}$ & $0.599^{\mathrm{Be}}$ & $0.502^{\mathrm{Bd}}$ & $0.480^{\mathrm{ABd}}$ & $0.468^{\mathrm{ABC}}$ & $0.165^{*}$ \\
\hline 3 & $0.866^{\mathrm{Ab}}$ & $0.716^{\mathrm{Cb}}$ & $0.693^{\mathrm{Cc}}$ & $0.642^{\mathrm{Bd}}$ & $0.610^{\mathrm{Bc}}$ & $0.594^{\mathrm{BCc}}$ & $0.560^{\mathrm{Bb}}$ & $0.153^{*}$ \\
\hline 4 & $1.672^{\mathrm{Aa}}$ & $0.845^{\mathrm{Dab}}$ & $0.801^{\mathrm{Db}}$ & $0.769^{\mathrm{Cc}}$ & $0.711^{\mathrm{Cab}}$ & $0.699^{\mathrm{Dc}}$ & $0.632^{\mathrm{BCb}}$ & $0.972^{*}$ \\
\hline 5 & ----- & $0.974^{\mathrm{Aa}}$ & $0.932^{\mathrm{Ea}}$ & $0.859^{\mathrm{Db}}$ & $0.811^{\mathrm{Cb}}$ & $0.771^{\mathrm{Db}}$ & $0.703^{\mathrm{CDab}}$ & $0.091^{*}$ \\
\hline 6 & ---- & ---- & ----- & $0.985^{\mathrm{Ea}}$ & $0.894^{\mathrm{Da}}$ & $0.869^{\mathrm{Aa}}$ & $0.813^{\mathrm{Aa}}$ & $0.009^{*}$ \\
\hline LSD & $0.168^{*}$ & $1.65^{*}$ & $0.172^{*}$ & $0.131^{*}$ & $0.147^{*}$ & $0.151^{*}$ & $0.127^{*}$ & \\
\hline
\end{tabular}

Where: Mean values in the same row (as a capital letter) or column (as a small letter) with the same letter are not significantly differences at 0.05 level; LSD: Least significant differences; Ns: Non-significant differences; * significant differences. 
Beef burgers prepared with volatile oils free and nano significantly increased as the time of frozen storage increased. This increase in TBA values during frozen storage could be indicated continues oxidation of lipids and consequently the production of oxidative by products. These results are in agreement with those obtained by Osheba (2013) who mentioned that TBA values of meat and chicken burger samples increased as the storage period increased. Furthermore, TBA values of beef burger treatments were decreased significantly by increasing volatile oil percentages. These results are in agreement with EL-Harery (1997) reported that TBA values of beef sausages decreased by increasing cardamom volatile oil concentrations. Control sample was unacceptable for human consumption after four months of storage as their TBA value reached (1.672 mg malonaldehyde $/ \mathrm{kg}$ sample), and according to Egyptian Standard specification (2005) rejected frozen beef burger samples which have more than $0.9 \mathrm{mg}$ malonaldehyde $/ \mathrm{kg}$ sample).are rejected Also, from the same Table, it could be observed that, TBA values are significantly affected by the type of volatile oils and their percentages normal and nano Cinnamon volatile oil free and nano had a higher effect on the reduction of TBA values than ginger volatile oil free and nano. This may be attributed to the stronger antioxidant of cinnamon components as reported by Shen and Kamdem, (2015) who said that cinnamon might be considered as potential antioxidant compared with ginger.

\section{CONCLUSION}

From this study it could be concluded that, the transformation of essential oils into nanoparticle size can affect their antioxidant activity and may promote the chemical properties and shelf life of beef burger.

\section{REFERENCE}

A. O. A. C., 1995. Official Methods of Analysis, 16th Ed. Association of Official Analytical Chemists, Arlington, Virginia, U.S.A.

Asnawi, S., Abd Aziz, A., Abd Aziz, R., Khamis, A.K., 2008. Formulation of geranium oil loaded solid lipid nanoparticles for mosquito repellent application. J. Chem. Nat. Res. Eng., 2, 90-99.

Cunha, C.M.L., Monteiro, M.L.G., Lorenzo, J.M Munekata, P.E.S., Muchenje, V., de Carvalho F.A. L.,Conte-Junior, C.A., 2018. Natural antioxidants in processing and storage stability of sheep and goat meat products. Food Res. Int., 111, 379-390.

Egyptian Standard Specifications, 2005. Edible sunflower seed oil. Egyptian Organization for Standardization and quality Control, No 49. Ministry of Industry and Trade. Egypt.

EL-Harery, A.S., 1997. Effect of Cardamom Oil on Chemical, Microbiological and Sensory Attributes of Beef Sausage. M.Sc. Thesis, Fac. Agric., Cairo Univ., Egypt.
Ghani, S., Barzegar, H., Noshad, M., Hojjati, M., 2018. The preparation, characterization and in vitro application evaluation of soluble soybean polysaccharide films incorporated with cinnamon essential oil nanoemulsions. Int. J. Biol. Macromol. 112, 197-202.

Gomah E., Nenaah., 2014. Chemical composition, toxicity and growth inhibitory activities of essential oils of three Achilleaspecies and their nano-emulsions against Tribolium castaneum (Herbst). Ind. Crops Prod., 53, 252-260.

Hassan, F.H.A., 2010. Studies on Microbiological and Chemical Characteristics of Some Meat Products. Ph.D. Thesis, Fac. Agric., Mansoura University, Egypt.

Mikkelson, V.L., 1993. Hamburger Patty Technology: A Literature Review. Technical Report, Meat Industry Research Institute of New Zealand (Inc.), MIRINZ 932 ISSN 0465-4390.

Moawad, R.K., 1995. Effect of Pretreatment on Quality Attributes and Nutritive Value of Frozen Beef and Chicken Meats. Ph.D. Thesis, Food Science and Technology Dept., Faculty of Agric., Cairo Univ.

Mohamed, H.A., 2005. Low Fat Products as Prepared from Ostrich and Other Produced Fat Beef. Ph.D. Thesis Nutrition and Food Science. Dept. Faculty of Home Economics. Minufiya University. Egypt.

Mwansyemela, N.A., 1973. Report on studies of routine analysis for food chemistry. Institute for fishery products TNO at Ijmuiden, Holland, 2nd April to 15th Sept.

Nayak, A.P., Tiyaboonchai, W., Patankar, S., Madhusudhana, B., Souto, E.B., 2010. Curcuminoids-loaded lipid nanoparticles: Novel approach towards malaria treatment. Colloid Surface B., 81, 263-273.

Sharma, P.K., Singh, V., Ali, M., 2016. chemical composition and antimicrobial activity of fresh rhizome essential oil of Zingiber officinale Roscoe. J. Pharmacogn., 8 (3), 185-190.

Shen, Z., Kamdem, D.P., 2015. Development and characterization of biodegradable chitosan films containing two essential oils. Int. J. Biol. Macromol., 74, 289-296.

Si W., Chen P.Y., Zhang J., Chen Z., Chung Y.H., 2018. Antioxidant activities of ginger extract and its constituents toward lipids. Food Chem. 239, 11171125.

Snedecor, G.W., Cochran, W.G., 1995. Statistical Methods (8th ed.). Oxford and IBH Pub., New Delhi, India.

Co.Winton, A.L., Winton, R.B., 1958. Okoloff Mangnesium Oxide Distillation VolumetricMethods. The Analysis of Food. John Wiley, New York, USA, 848 p.

Tarladgis, B.G., Watts, B.M., Younathan, M.T., Dugan, L., 1960. A distillation method for the quantitative determination of malonaldehyde in rancid food. J. Am. Oil. Chem. Soc., 37, 44-48.

Tiyaboonchai, W., Tungpradit, W., Plianbangchang, P., 2007. Formulation and characterization of curcuminoids loaded solid lipid nanoparticles, Int. J. Pharm. 337, 299-306.

Wang, H.F., Wang, Y.K., Yih, K.Y., 2008. DPPH free-radical scavenging ability, total phenolic content, and chemical composition analysis of forty-five kinds of essential oils. J. Cosmet. Sci., 59 (6), 509-522.

Wang, R., Wang, R., Yang, B., 2009. Extraction of essential oils from five cinnamon leaves and identification of their volatile compound compositions. Innov. Food Sci. Emerg. Technol. 10 (2), 289-292.

Yang, F.L., Li, X.G., Zhu, F., Lei, C.L., 2009. Structural characterization of nanoparticles loaded with garlic essential oil and their insecticidal activity against Tribolium castaneum (Herbst) (Coleoptera: Tenebrionidae). J. Agric. Food Chem., 57, 1015610162. 


\section{استخدام الزيوت العطرية في صورتها العادية والمتناهية الصغر كضادات أكسدة}

محمد جابر عبد الفضيل طه 1، محمد مبروك الدناصوري 1، محمود فرحات سيد عواد²، محمد الشحات عبد الله مغازي2

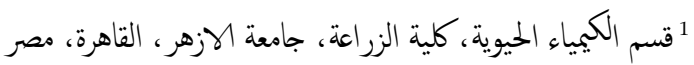

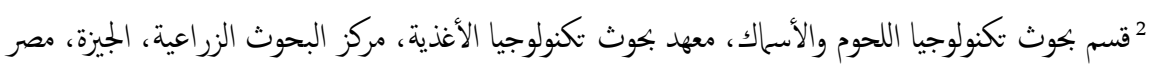
mdanasory@azhar.edu.eg البريد الإليكتروني للباحث الرئيسي: *

الملخص العربي

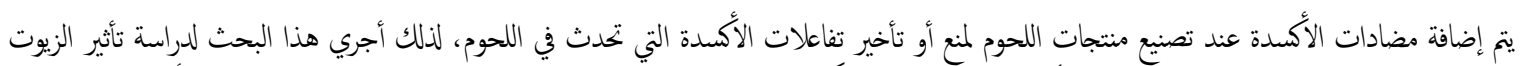

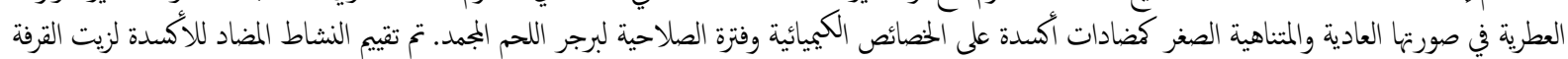

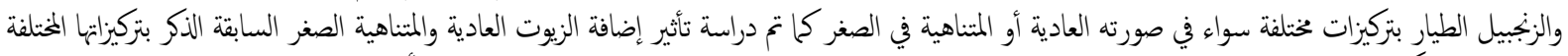

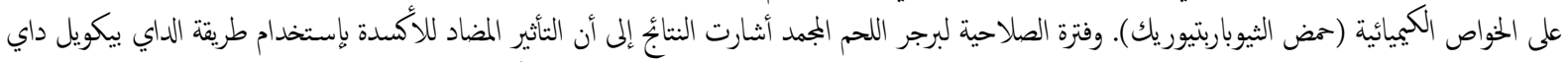

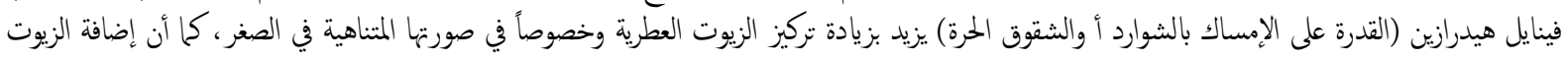

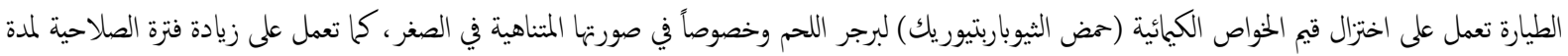

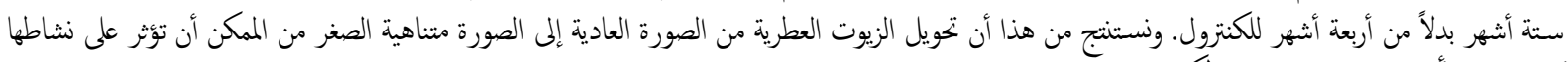

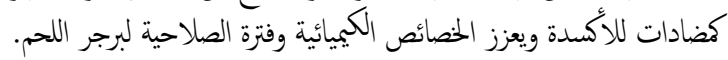

الكلمات المفتاحية: الزيوت طيارة، مضادة للأكسدة، قرفة، زنجبيل. 